\title{
PENERAPAN PENDEKATAN OPEN-ENDED UNTUK MENINGKATKAN KEMAMPUAN BERPIKIR KREATIF MATEMATIS SISWA MTS
}

\author{
RATNA NURWAHIDAH, VARA NINA YULIAN, MARIAM AR RAHMAH
}

ratnanurwahidah@gmail.com

Pendidikan Matematika

Fakultas Keguruan dan Ilmu Pendidikan

Universitas Subang

\begin{abstract}
ABSTRAK
Penelitian ini karena kemampuan berpikir kreatif matematis siswa masih kurang, masih banyak siswa yang mengalami kesulitan mengerjakan soal-soal matematika, selain itu juga siswa terlihat pasif dan hanya mengikuti contoh penyelesaian yang dilakukan oleh guru. Salah satu pendekatan pembelajaran yang dapat meningkatkan kemampuan berpikir kreatif matematis siswa adalah pendekatan Open-Ended. Subjek dalam penelitian ini adalah siswa kelas VII MTs Al-Fatah Pabuaran. Peneliti memilih dua kelas sebagai sampel. Satu kelas sebagai kelas eksperimen yang diberikan perlakuan dengan pendekatan pembelajaran Open-Ended, dan satu kelas sebagai kelas kontrol yang diberi perlakuan dengan metode pembelajaran ekspositori. Dalam penelitian ini desain yang digunakan adalah pretes-postes Control Group Design. Dari hasil uji hipotesis rerata indeks gain dapat disimpulkan bahwa peningkatan kemampuan berpikir kreatif matematis siswa antara kelas yang menggunakan pendekatan Open-Ended lebih baik daripada kelas yang menggunakan metode ekspositori. Hal tersebut terlihat pada saat proses belajar mengajar dalam kelas, siswa terlihat antusias dalam mengerjakan soal Open-Ended dan menjawab soal tersebut dengan berbagai alternatif jawaban. Hasil tersebut diperkuat oleh data angket yang menggambarkan bahwa respon siswa positif dan siswa menjadi lebih kreatif dalam pembelajaran matematika dengan menggunakan pendekatan pembelajaran Open-Ended. Dengan demikian pendekatan Open-Ended dapat dijadikan sebagai salah satu alternatif pembelajaran selama dikelas untuk meningkatkan kemampuan berpikir keatif matematis siswa MTs.
\end{abstract}

Kata kunci : Kemampuan Berpikir Kreatif Matematis, Pendekatan Pembelajaran Open-Ended, Metode Pembelajaran Ekspositori.

\section{PENDAHULUAN}

Rendahnya kemampuan berpikir kreatif siswa muncul karena seseorang terlalu dibiasakan untuk berpikir secara prosedural. Menurut Purwaningrum (2016) orang yang yang berpikir secara prosedural adalah orang yang terbiasa mengikutin pola bersikap dan berperilaku sebagaimana pola yang dikembangkan oleh lingkungannya. Selain dari itu, metode pembelajaran yang diterapkan di kelas masih menggunakan metode ekspositori yaitu pembelajaran yang berpusat pada guru (teacher center). 
Namun sayangnya kemampuan matematika siswa MTs masih kurang, hal ini dibuktikan ketika penulis melakukan observasi dan wawancara dengan guru mata pelajaran matematika di kelas VIII MTs Al-Fatah Pabuaran yang menyatakan bahwa masih banyak siswa yang mengalami kesulitan dalam mengerjakan soal-soal matematika, hal ini dilihat dari banyaknya siswa yang mendapat nilai rendah yakni dibawah KKM (Kriteria Kelulusan Minimal), selain itu juga siswa terlihat pasif dan hanya mengikuti contoh penyelesaian yang diberikan oleh guru. Akibatnya ketika siswa lupa langkah-langkah pengerjaannya, maka siswa tidak bisa mengerjakan soal yang diberikan. Seperti dalam penelitian Kholil (2015) bahwa dalam proses pembelajaran sebelumnya dengan menggunakan model ekspositori para siswa kurang kreatif karena mereka cenderung untuk mengikuti penjelasan dari guru tanpa ada pemahaman terhadap konsep matematika, rata-rata para siswa cenderung menghafal rumus-rumus dan langkah-langkah dalam mengerjakan soal-soal sehingga kreativitas siswa dalam berpikir belum berkembang. Hal ini terjadi karena belum dilakukannya inovasi dalam pendekatan pembelajaran atau belum diterapkannya pendekatan Open-Ended dalam pembelajaran matematika di kelas tersebut.

Oleh karena itu, untuk mengatasi permasalahan tersebut, perlu dilakukan sebuah inovasi yakni dengan menerapkan model atau pendekatan pembelajaran yang tepat agar dapat meningkatkan kemampuan berpikir kreatif siswa dalam memecahkan masalah. Maka untuk merangsang kemampuan berpikir kreatif siswa, kegiatan pembelajaran harus membawa siswa dalam menjawab permasalahan dengan banyak cara dan mungkin juga banyak jawaban (yang benar) sehingga dapat mengundang potensi intelektual dan pengalaman siswa dalam menemukan sesuatu yang baru.

Penulis menawarkan sebuah pendekatan yang diharapkan dapat meningkatkan kemampuan berpikir kreatif matematis siswa. Pendekatan tersebut adalah pendekatan open-ended. Karena menurut pendapat Muhsinin (2013) pendekatan open-ended adalah salah satu pendekatan dalam pembelajaran matematika yang memberikan kebebasan berpikir kepada siswa secara aktif dan kreatif. Dengan menggunakan pendekatan ini guru dituntut untuk dapat memberikan permasalahan yang memiliki penyelesaian yang benar lebih dari satu cara, sehingga siswa dapat menggunakan pengetahuan matematikanya masingmasing untuk menyelesaikan permasalahan tersebut.

Menggunakan kreativitas dan kebebasan dalam menyelesaikan permasalahan matematika membuat kemampuan berpikir kreatif matematis siswa dapat meningkat. Hubungan antara pendekatan open-ended dengan kemampuan berpikir kreatif dapat kita simpulkan dari penjelasan sebelumnya. Pendekatan open-ended pembelajaran matematika yang memberikan kebebasan berpikir kepada siswa secara aktif dan kreatif. Penuturan di atas membuat penulis tertarik untuk meneliti di MTs dengan judul "Penerapan Pendekatan Open-Ended untuk Meningkatkan Kemampuan Berpikir Kreatif Siswa MTs”.

Berdasarkan latar belakang yang sudah diuraikan diatas, rumusan masalah yang akan dibahas adalah sebagai berikut :

1. Apakah peningkatan kemampuan berpikir kreatif matematis siswa yang pembelajarannya dengan pendekatan Open-Ended lebih baik daripada 
kemampuan berpikir kreatif matematis siswa yang menggunakan pembelajaran ekspositori?

2. Bagaimanakah sikap siswa terhadap pembelajaran matematika dengan menggunakan pendekatan Open-Ended?

\section{METODE PENELITIAN}

Penelitian ini adalah penelitian dengan quasi eksperiment atau eksperimen semu dengan menggunakan dua kelompok. Kelompok pertama sebagai kelas eksperimen dan kelompok kedua sebagai kelas kontrol. Pada kelas eksperimen diterapkan pembelajaran menggunakan pendekatan Open-Ended sedangkan kelas kontrol menggunakan metode ekspositori. Pada saat penelitian, peneliti menggunakan kelas-kelas yang telah tersedia karena peneliti tidak mungkin mengelompokkan siswa secara acak. Jika dilakukan pengacakan kelas, maka akan mengganggu efektivitas kegiatan pembelajaran di sekolah. Agar diperoleh gambaran dari perlakuan maka dipilihlah kelompok pembanding. Penelitian ini menggunakan desain kelompok Pretest-Postest Control Group Design menurut Guilford (Lestari, 2015) dengan desain sebagai berikut :

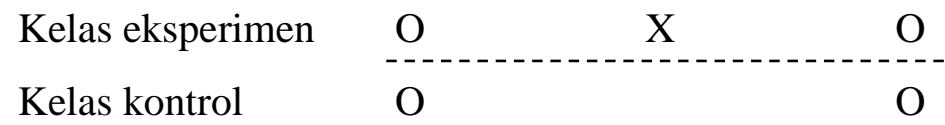

Dengan keterangan :

$\mathrm{O}=$ Tes awal, tes akhir pada kelompok eksperimen dan kontrol.

$\mathrm{X}=$ Perlakuan pembelajaran pendekatan Open-Ended.

------ = Subjek tidak dikelompokan secara acak.

Menurut Sugiyono (2012) populasi adalah wilayah generalisasi yang terdiri atas objek/subjek yang mempunyai kualitas dan karakteristik tertentu yang diterapkan oleh peneliti untuk dipelajari dan kemudian ditarik kesimpulannya. Populasi dalam penelitian ini adalah seluruh siswa kelas VII di salah satu MTs yang ada di Kecamatan Pabuaran Kabupaten Subang yang terbagi ke dalam 6 kelas. Sampel adalah bagian dari jumlah dan karakteristik yang dimiliki oleh populasi tersebut. Sampel penelitian ditentukan berdasarkan purposive sampling, yaitu teknik pengambilan sampel yang berdasarkan pertimbangan tertentu (Sugiyono, 2012) sehingga dipilih dua kelas dari seluruh kelas VII di sekolah tersebut. Pertimbangan yang digunakan dalam pemilihan sampel adalah dari informasi yang diperoleh dari kepala sekolah, wali kelas dan guru mata pelajaran matematika yang mengajar di kelas VII yang menyatakan bahwa kelas VII memiliki kemampuan akademik yang hampir sama. Pemilihan sampel dengan purposive sampling bertujuan agar penelitian dapat berlangsung secara tepat, efektif, dan efisien dalam hal pelaksanaan penelitian, waktu penelitian, tempat penelitian dan administrasi. Dua kelompok yang dipilih sebagai sampel penelitian adalah kelompok eksperimen siswa kelas VII sebanyak 30 siswa yang menggunakan pendekatan Open-Ended, dan kelompok kontrol siswa kelas VII sebanyak 30 siswa yang menggunakan metode pembelajaran ekspositori. 


\section{HASIL PENELITIAN}

Data yang diperoleh dari penelitian ini adalah data dari hasil pretes (tes awal) dan postes (tes akhir) yang diberikan pada kelas eksperimen dan kelas kontrol. Selanjutnya data yang telah diperoleh dianalisis sehingga dapat memudahkan peneliti dalam mengambil kesimpulan. Berikut ini hasil analisis uji perbedaan dua rerata pretes :

Tabel 1. Hasil Uji Perbedaan Dua Rerata Pretes Test Statistics ${ }^{\mathrm{a}}$

\begin{tabular}{|l|r|}
\hline & $\begin{array}{c}\text { Kemampuan } \\
\text { Berpikir Kreatif }\end{array}$ \\
\hline Mann-Whitney U & 428,500 \\
Wilcoxon W & 893,500 \\
Z & $-0,324$ \\
Asymp. Sig. (2-tailed) & 0,746 \\
\hline
\end{tabular}

Berdasarkan hasil perhitungan pada tebal 1 diatas dengan menggunakan uji non-parametrik Mann-Whitney, diperoleh nilai signifikansi sebesar 0,746. Nilai signifikansinya $\geq 0,005$ maka $\mathrm{H}_{0}$ diterima. Artinya tidak terdapat perbedaan kemampuan awal berpikir kritis matematis siswa kelas eksperimen dengan kelas kontrol. Berikut ini hasil analisis uji perbedaan dua rerata postes :

\section{Tabel 2. Hasil Uji Perbedaan Dua Rerata Postes} Test Statistics ${ }^{a}$

\begin{tabular}{|l|r|}
\hline & $\begin{array}{c}\text { Kemampuan } \\
\text { Berpikir Kreatif }\end{array}$ \\
\hline Mann-Whitney U & 149,000 \\
Wilcoxon W & 614,000 \\
Z & $-4,520$ \\
Asymp. Sig. (2-tailed) & 0,000 \\
\hline
\end{tabular}

a. Grouping Variable: Kelas

Berdasarkan hasil perhitungan pada tabel 2 diatas dengan uji non parametrik Mann-Whitney, diperoleh nilai signifikansi sebesar 0,000. Karena 0,000 $<0,05$ maka $\mathrm{H}_{0}$ ditolak. Artinya terdapat perbedaan kemampuan akhir berpikir kreatif matematis siswa yang menggunakan pendekatan pembelajaran Open-Ended dengan siswa yang menggunakan metode pembelajaran ekspositori. Berikut ini hasil analisis uji perbedaan dua rerata indeks gain : 
Tabel 3. Hasil Uji Perbedaan Dua Rerata Indeks Gain Test Statistics ${ }^{a}$

\begin{tabular}{|l|r|}
\hline & $\begin{array}{c}\text { Kemampuan } \\
\text { Berpikir Kreatif }\end{array}$ \\
\hline Mann-Whitney U & 106,500 \\
Wilcoxon W & 571,500 \\
Z & $-5,087$ \\
Asymp. Sig. (2-tailed) & 0,000 \\
\hline \multicolumn{2}{|l}{} \\
a. Grouping Variable: Kelas
\end{tabular}

Berdasarkan hasil uji perbedaan dua rerata indeks gain pada tabel 3 diatas, diperoleh nilai signifikansi sebesar 0,000. Karena 0,000 lebih kecil dari 0,05 maka $\mathrm{H}_{0}$ ditolak. Artinya terdapat perbedaan peningkatan kemampuan berpikir kreatif matematis siswa yang pembelajarannya menggunakan pendekatan Open-Ended lebih baik dari dengan yang pembelajarannya menggunakan metode ekspositori. Dalam hal ini berarti penerapan pendekatan Open-Ended dapat meningkatkan kemampuan berpikir kreatif matematis siswa MTs.

Data rekapitulasi hasil perhitungan skala sikap bertujuan untuk menge-tahui presentasi rata-rata sikap siswa terhadap kemampuan berpikir kreatif matematis siswa dengan menggunakan pendekatan Open-Ended.

Tabel 4. Data Rekapitulasi Hasil Perhitungan Skala Sikap

\begin{tabular}{|c|c|c|c|c|c|c|}
\hline \multirow{2}{*}{ Aspek } & \multirow{2}{*}{ Pernyataan } & \multirow{2}{*}{$\begin{array}{l}\text { No } \\
\text { Soal }\end{array}$} & \multicolumn{4}{|c|}{ Persentase } \\
\hline & & & SS & $\mathbf{S}$ & TS & STS \\
\hline \multirow{7}{*}{$\begin{array}{l}\text { Sikap terhadap pelajaran } \\
\text { matematika }\end{array}$} & \multirow{3}{*}{$\mathrm{P}$} & 1 & 36,67 & 46,67 & 10,00 & 6,67 \\
\hline & & 2 & 16,67 & 53,33 & 23,33 & 6,67 \\
\hline & & 3 & 33,33 & 50,00 & 6,67 & 10,00 \\
\hline & Rata-rata & & 28,89 & 50,00 & 13,33 & 7,78 \\
\hline & \multirow{2}{*}{$\mathrm{N}$} & 4 & 3,33 & 23,33 & 60,00 & 13,33 \\
\hline & & 5 & 10,00 & 20,00 & 50,00 & 20,00 \\
\hline & Rata-rata & & 6,67 & 21,67 & 55,00 & 16,67 \\
\hline \multirow{14}{*}{$\begin{array}{c}\text { Sikap terhadap } \\
\text { pendekatan pembelajaran } \\
\text { Open-Ended }\end{array}$} & \multirow{10}{*}{$\mathrm{P}$} & 6 & 16,67 & 66,67 & 16,67 & 0,00 \\
\hline & & 7 & 10,00 & 46,67 & 43,33 & 0,00 \\
\hline & & 8 & 16,67 & 56,67 & 23,33 & 3,33 \\
\hline & & 9 & 30,00 & 63,33 & 6,67 & 0,00 \\
\hline & & 10 & 23,33 & 63,33 & 13,33 & 0,00 \\
\hline & & 11 & 10,00 & 56,67 & 30,00 & 3,33 \\
\hline & & 12 & 36,67 & 23,33 & 40,00 & 0,00 \\
\hline & & 13 & 40,00 & 30,00 & 20,00 & 10,00 \\
\hline & & 14 & 33,33 & 30,00 & 30,00 & 6,67 \\
\hline & & 15 & 16,67 & 50,00 & 23,33 & 10,00 \\
\hline & Rata-rata & & 23,33 & 48,67 & 24,67 & 3,33 \\
\hline & \multirow{3}{*}{$\mathrm{N}$} & 16 & 6,67 & 10,00 & 50,00 & 33,33 \\
\hline & & 17 & 10,00 & 20,00 & 53,33 & 16,67 \\
\hline & & 18 & 16,67 & 10,00 & 53,33 & 20,00 \\
\hline
\end{tabular}




\begin{tabular}{|c|c|c|c|c|c|c|}
\hline \multirow{2}{*}{ Aspek } & \multirow{3}{*}{ Pernyataan } & \multirow{2}{*}{ No } & \multicolumn{4}{|c|}{ Persentase } \\
\cline { 3 - 7 } & & Soal & SS & S & TS & STS \\
\cline { 3 - 7 } & & 19 & 0,00 & 23,33 & 56,67 & 20,00 \\
\cline { 3 - 7 } & & 20 & 33,33 & 30,00 & 23,33 & 13,33 \\
\cline { 3 - 7 } & Rata-rata & & $\mathbf{1 3 , 3 3}$ & $\mathbf{1 8 , 6 7}$ & $\mathbf{4 7 . 3 3}$ & $\mathbf{2 0 , 6 7}$ \\
\hline \multirow{4}{*}{$\begin{array}{c}\text { Sikap terhadap soal } \\
\text { kemampuan berpikir } \\
\text { kreatif }\end{array}$} & \multirow{3}{*}{$\mathrm{P}$} & 21 & 20,00 & 40,00 & 23,33 & 16,67 \\
\cline { 3 - 7 } & & 22 & 30,00 & 33,00 & 23,33 & 13,33 \\
\cline { 3 - 7 } & Rata-rata & & $\mathbf{1 8 , 8 9}$ & $\mathbf{4 5 , 5 6}$ & $\mathbf{2 5 , 5 6}$ & $\mathbf{1 0 , 0 0}$ \\
\cline { 3 - 7 } & \multirow{2}{*}{$\mathrm{N}$} & 24 & 10,00 & 16,67 & 60,00 & 13,33 \\
\cline { 3 - 7 } & & 25 & 0,00 & 20,00 & 50,00 & 30,00 \\
\cline { 3 - 7 } & Rata-rata & & $\mathbf{5 , 0 0}$ & $\mathbf{1 8 , 3 3}$ & $\mathbf{5 5 , 0 0}$ & $\mathbf{2 1 , 6 7}$ \\
\hline
\end{tabular}

Tabel 4 memperlihatkan bahwa rata-rata pernyataan positif terhadap pelajaran matematika memberikan tanggapan sangat setuju dan setuju sebesar $78,89 \%$, tanggapan tidak setuju dan sangat tidak setuju sebesar $21,11 \%$, sedangkan rata-rata pernyataan negatif memberikan tanggapan sangat setuju dan setuju sebesar $28,34 \%$, tanggapan tidak setuju dan sangat tidak setuju sebesar $71,67 \%$. Dilihat dari pernyataan positif dan negatif, hal ini dapat disimpulkan bahwa hampir seluruh siswa menyukai mata pelajaran matematika.

Kemudian rata-rata pernyataan positif terhadap pendekatan pembelajaran Open-Ended memberikan tanggapan sangat setuju dan setuju sebesar 72,00\%, tanggapan tidak setuju dan sangat tidak setuju sebesar 28,00\%, sedangkan rata-rata pernyataan negatif memberikan tanggapan sangat setuju dan setuju sebesar 32,00\%, tanggapan tidak setuju dan sangat tidak setuju sebesar 68,00\%. Hal ini dapat disimpulkan untuk pernyataan positif pada umumnya siswa memberi respon positif, sedangkan untuk pernyataan negatif sebagian besar siswa memberi respon negatif terhadap belajar dengan menggunakan pendekatan pembelajaran Open-Ended. Dilihat dari pernyataan positif dan negatif, hal ini dapat disimpulkan bahwa hampir seluruh sikap siswa cenderung positif terhadap penerapan pendekatan Open-Ended dalam pembelajaran.

Kemudian rata-rata pernyataan positif terhadap soal-soal berpikir kreatif matematis memberikan tanggapan sangat setuju dan setuju sebesar 64,45\%, tanggapan tidak setuju dan sangat tidak setuju sebesar 35,55\%, sedangkan rata-rata pernyataan negatif memberikan tanggapan sangat setuju dan setuju sebesar 23,33\%, tanggapan tidak setuju dan sangat tidak setuju sebesar 76,67\%. Hal ini dapat disimpulkan untuk pernyataan positif hampir seluruh siswa memberi respon positif, sedangkan untuk pernyataan negatif pada umumnya siswa memberi respon negatif terhadap soal-soal kemampuan berpikir kreatif matematis. Dilihat dari pernyataan positif dan negatif, hal ini dapat disimpulkan bahwa hampir seluruh sikap siswa cenderung positif terhadap soal berpikir kreatif dalam pembelajaran.

\section{KESIMPULAN}

Berdasarkan hasil penelitian dan pembahasan mengenai penerapan pendekatan pembelajaran Open-Ended untuk meningkatkan kemampuan berpikir 
kreatif matematis siswa MTs yang dilakukan, dapat diperoleh kesimpulan sebagai berikut :

1. Peningkatan kemampuan berpikir kreatif matematis siswa yang pembelajarannya dengan pendekatan Open-Ended lebih baik daripada kemampuan berpikir kreatif matematis siswa yang menggunakan metode pembelajaran ekspositori.

2. Siswa memiliki sikap positif terhadap pembelajaran matematika dengan menggunakan pendekatan Open-Ended.

Berdasarkan hasil penelitian, pembahasan dan kesimpulan mengenai pendekatan Open-Ended, peneliti akan memberikan saran-saran sebagai berikut :

1. Pembelajaran matematika dengan menggunakan pendekatan Open-Ended hendaknya menjadi salah satu variasi pembelajaran di kelas, terutama untuk meningkatkan kemamuan berpikir kreatif matematis siswa.

2. Pembelajaran matematika dengan pendekatan pembelajaran Open-Ended dapat diterapkan untuk semua siswa dalam meningkatkan kemampuan berpikir kreatif siswa di MTs, namun guru harus lebih banyak memberikan latihanlatihan soal terbuka untuk siswa dan harus memperhatikan pembagian kelompok agar terbentuk kelompok yang heterogen.

3. Pemilihan soal dengan pendekatan Open-Ended harus lebih mudah dipahami dan diusahakan untuk lebih sering menggunakan bahasa kehidupan sehari-hari sehingga siswa mampu menggunakan daya berpikir kreatif untuk memperkirakan kemungkinan-kemungkinan jawaban benar.

4. Dalam penerapan pendekatan Open-Ended di kelas, sebaiknya guru membuat skenario pembelajaran yang matang, sehingga pembelajaran dapat terlaksana secara sistematis dan prosedural sesuai dengan rencana. Perlu dikembangkan oleh guru soal-soal untuk meningkatkan kemampuan berpikir kreatif matematis siswa, agar siswa terbiasa mengerjakan soal-soal tersebut sehingga dapat meningkatkan keterampilan siswa dalam berpikir dan meningkatkan kreativitas siswa.

5. Bagi peneliti selanjutnya, penelitian ini dapat dilanjutkan untuk melihat pengaruh pendekatan Open-Ended ini terhadap kemampuan matematis yang lainnya seperti kemampuan pemahaman, kemampuan komunikasi, representasi matematis dan perlu dilakukan penelitian lanjutan untuk level sekolah yang tinggi dan sedang atau terhadap jenjang pendidikan lain seperti sekolah dasar dan sekolah menengah atas.

\section{DAFTAR PUSTAKA}

Kholil, Mohammad. (2015). "Pembelajaran dengan Pendekatan Open-Ended untuk Meningkatkan Kemampuan Berpikir Kreatif". Jurnal Fenomena. Volume 14 Nomor 2

Lestari, Karunia Eka., dan Yudhanegara, Ridwan Mokhammad. (2015). "Penelitian Pendidikan Matematika". Bandung. PT. Refika Aditama

Muhsinin. (2013). "Pendekatan Open-Ended pada Pembelajaran Matematika". Jurnal Edu-Math. Volume 1 Nomor 4

Sugiyono. (2012). “Metode Penelitian Kuantitatif Kualitatif dan R\&D”. Bandung. Alfabeta 